\title{
Caballero de fina estampa. In memoriam de don Antonio Bonet Correa
}

Esa frase de la hermosa canción que Chabuca Granda dedicó a su padre, considero que es un buen recurso para recordar la imagen del gran intelectual y extraordinario maestro de la historia del arte, desaparecido hace escasos meses. Tuve la fortuna de ser su alumno cuando iniciaba mis estudios universitarios y muy pronto pude advertir no solo su poderosa y fascinante personalidad, sino también su profundo saber humanista, su desbordante entusiasmo y su talante renovador. Quienes asistíamos a sus clases y a las actividades complementarias, a las visitas a monumentos y a sus conferencias, pudimos disfrutar de sus perspicaces análisis y chispeantes comentarios. Mientras advertíamos la novedad de sus enfoques metodológicos nos incitaba a procurar un horizonte científico ambicioso, a disfrutar de nuestra disciplina y a sacar todo el jugo posible a la vida. Eran las sabias recomendaciones de quien fue una persona profundamente vitalista, un lector apasionado y viajero infatigable que mantuvo a lo largo de su vida el afán de los años juveniles por ver y conocer, que hicieron de él un verdadero cosmopolita.

Don Antonio Bonet fue además un sagaz observador, con una curiosidad intelectual permanente y desbordante, con múltiples intereses como demuestra su extensísima y variadísima producción bibliográfica, que abarcó desde el arte prerrománico asturiano a los últimos movimientos artísticos, habiendo prestado especial atención a la arquitectura, al urbanismo, al arte de la América virreinal y, sobre todo, a las creaciones del Barroco, periodo sobre el que fue reconocido internacionalmente como gran especialista. Sus numerosas aportaciones han tenido la virtud de abrir nuevos caminos a la investigación y de convertirse en acicate para quienes hemos tratado de seguir sus huellas. No menos valiosa y amplia fue su carrera docente, que dejó profunda huella en varias generaciones de historiadores del arte por las distintas universidades en las que ejerció su magisterio. En ellas dirigió numerosas tesis doctorales, siendo también miembro de tribunales de muchas otras que se presentaron y defendieron por toda la geografía española. Esa vinculación con las instituciones universitarias, su magisterio y prestigio hicieron que varias de ellas lo reconocieran como doctor honoris causa. Por otra parte, su fecunda labor explica los numerosos honores, premios y homenajes que recibió a lo largo de sus muchos años de frenética actividad.

A ese ingente cometido hay que sumar su labor como asesor de colecciones y museos, su condición de jurado de certámenes y concursos, su vinculación con la crítica artística y con las ferias de arte. Igualmente relevante fue su tarea como editor, que hizo posible poner al alcance de los estudiosos del arte en España textos sobre las más variadas materias, elaborados por reconocidos especialistas. Su dilatada y variada actividad incluyó el ámbito de los museos, llegando a ocupar la dirección de algunas instituciones y colaborando con otras en calidad de miembro de sus patronatos o a través de fundaciones a ellas vinculadas. Muy fructíferos fueron sus años como académico de San Fernando, institución que llegó a dirigir con eficacia y brillantez. Reconocida fue su labor como comisario de exposiciones, en las que puso de manifiesto no solo su sabiduría y rigor científico, sino también su capacidad para la comunicación y la difusión. Muy valiosa y significativa fue su dedicación a la tutela del patrimonio histórico. Participó en el seguimiento de la elaboración de los inventarios artísticos, se interesó por rescatar del olvido piezas singulares de nuestro acervo patrimonial, desarrolló labores de asesoramiento en instituciones y actuó como representante de organismos internacionales en comisiones y comités. En este campo es obligado destacar sus esfuerzos por la protección de nuestra riqueza patrimonial desde la presidencia del organismo nacional consultivo responsable de la exportación e importación de los bienes culturales protegidos, de su valoración, de la posible adquisición de otros y de la realización de las estimaciones oportunas para la puesta en práctica de las medidas de fomento. 
A lo largo de toda su trayectoria don Antonio Bonet hizo gala de una aguda inteligencia y de una innata simpatía que le permitían conversar de todo y con todos sin marcar artificiales distancias. Por su proximidad y su cordial talante recibió la admiración y el afecto de muchos, especialmente de los más jóvenes, que lo veían como el gran maestro y como un referente. Su apasionamiento, jovialidad y espíritu renova- dor deben servir de estímulo a las nuevas generaciones a fin de alcanzar esa vida plena que el gozó hasta el último momento sin perder jamás su porte distinguido, su pulcra y elegante indumentaria, «su fina estampa» de caballero.

Alfredo J. Morales Universidad de Sevilla 